\title{
Effect of ABA and GA3 on Protein Mobilization in Embryos and Cotyledons of Angico [Anadenanthera peregrina (L.) speg] Seeds During Germination.
}

\author{
Douglas Barduche $^{1 *}$, Renato Paiva ${ }^{1}$, Mauricio A. Lopes ${ }^{2}$ and Edilson Paiva ${ }^{2}$ \\ ${ }^{I}$ Departamento de Biologia, Universidade Federal de Lavras, CP 37,CEP 37200-000, Lavras, MG, Brasil. ${ }^{2}$ Núcleo \\ de Biologia Aplicada, CNPMS/EMBRAPA, CP 151, CEP 35701-970, Sete Lagoas, MG, Brasil
}

\begin{abstract}
In this work, a woody species [A. peregrina (L.) Speg.] was studied in order to observe the effect of $A B A$ and $G A_{3}$ at the biochemical level during the process of seed germination. Embryos incubated in sucrose solution containing $A B A$ and/or $G A_{3}$ were analyzed through SDS-PAGE to observe the mobilization pattern of storage proteins during the beginning of germination. Cotyledons isolated from seeds incubated in aqueous solutions containing ABA and/or $\mathrm{GA}_{3}$, were also analyzed through SDS-PAGE and by PAGE/Activity Gels (polyacrylamide gels copolymerized with substrate for enzymes) to observe the mobilization pattern of storage proteins and protease activity after the beginning of the germination. Results of these experiments show that ABA blocks protein mobilization by inhibiting protease activity in cotyledons. This inhibition is not sufficient to prevent germination showing that the effect of ABA on germination is not dependent on protease activity. The blockage of storage protein mobilization was also observed in embryos, but no protease activity inhibition was clearly detected. ABA was able to induce the synthesis of proteins in cotyledons but not in embryos. A polypeptide with an approximate molecular weight of $17 \mathrm{kD}$, was degraded within 6 hours in control embryos, but this degradation was blocked by ABA and $G A_{3}$. Using the same concentrations of $A B A$ and $G A_{3}$ on embryos and cotyledons, the effect of $A B A$ was counteracted by $G A_{3}$ in embryos, but not in cotyledons. Although the effects of $A B A$ and $G A_{3}$ were not so different from those shown in the literature, the behavior of $17 \mathrm{kD}$-polypeptide contradicts these reports suggesting that specific studies should be performed.
\end{abstract}

Key words: $\mathrm{ABA}, \mathrm{GA}_{3}$, germination, protein pattern, protease activity, tropical woody plant.

\section{INTRODUCTION}

Seeds of cultivated species have been used as experimental models in studies of biochemical mechanisms of the germinative process, such as synthesis and mobilization of seed reserves (Fincher, 1989; Shotwell \& Larkins, 1989; Shutov \& Vaintraub, 1987; Ryan, 1973); characterization of storage proteins (Shewry et al, 1995; Barros \& Larkins, 1981; Larkins, 1981) or hormonal control of hydrolase synthesis by the aleurone layer of cereals (Nolan \& Ho, 1988; Jacobsen \& Beach, 1985).

The use of these seeds as experimental models has the convenience of being genetically uniform in the same population. In general, this implies into an uniform germination. However, especifically for this uniformity, Mayer and
Shain (1974) suggest that "these species are not ideal models for the comprehension of the mechanisms which control germination as a whole".

Wild species do not present this uniformity. Seeds of wild species which present dormancy are under a complex mechanism of germination control. Polymorphous species that present seeds of different sizes, shapes and mass, can throw seeds in the soil at different stages of development, thus leading dormancy to occur in different degrees of intensity (Mayer \& Poljakoff-Mayber, 1989). Dormancy variability implies distinct germinative behaviors that allow the dispersion of germination along with time and space, which in turn prevents the occurrence of mass germination under possible unfavorable 
environmental conditions (Mayer \& PoljakoffMayber, 1989; Mayer \& Shain, 1974).

Among the factors controlling germination, are the endogenous levels of phytohormones mediating alterations of seed physiological and biochemical state which result in resuming the embryo development. These alterations are complex and converge for the activation and synthesis de novo of hydrolytic enzymes which break the reserve macromolecules. The products of the hydrolyses are then used for the growth of the embryo axis (Fincher, 1989).

The protein synthesis presents distinct patterns during the germinative process (Oishi \& Bewley, 1992) and the phytohormones have a key role in inducing or repressing this synthesis. In studies of the germinative process, emphazis has been given to the influence of gibberellins (GAs) and abscisic acid (ABA), due to the antagonism between them in relation to their promoting and inhibiting effects on germination, respectively (McCarty, 1995; van Beckum et al, 1993; Qi et al, 1992; Kohler \& Ho, 1990; Nolan \& Ho, 1988; Jacobsen \& Beach, 1985, Schopfer \& Plachy, 1985; Higgins et al , 1976; Harvey \& Oaks, 1974).

It is a concensus that the GAs are the embryo's diffusive factors for the aleurone layer in cereals and that they promote synthesis of hydrolases through this layer during germination. This concensus comes from studies performed with aleurone layer isolated from barley of the Himalaya cultivar. Aleurone of this barley cultivar has been used as an experimental model to study the effects of $\mathrm{GA}_{3}$. The $\mathrm{GA}_{3}$ pattern sensitivity is obtained from these aleurone layers, in which in the absence of this growth regulator, little or no $\alpha$-amylase is synthesized (Fincher, 1989). However, Fincher observes that "other cereals, including other barley varieties, are relatively insensitive to $\mathrm{GA}_{3}$ and it has not been demonstrated unequivocally that the GAs are diffusive factors in intact grains for all cases" (Fincher, 1989). However, what is known about the protein synthesis induced by $\mathrm{GA}_{3}$ during germination derives from studies with this model. In the aleurone layers, $\mathrm{GA}_{3}$ induces the expression of specific genes that codify for hydrolytic enzymes. For example,
$\mathrm{GA}_{3}$ is capable of inducing the mRNAs synthesis of $\alpha$-amylase (Nolan \& Ho, 1988; Jacobsen \& Beach, 1985), proteases (Kohler \& Ho, 1990; Nolan \& Ho, 1988), nucleases, $\beta$-glucanases and other hydrolases (Fincher, 1989). Besides inducing de novo proteases synthesis, $\mathrm{GA}_{3}$ also activates proteases secretion (Hammerton \& Ho, 1986; Jacobsen \& Varner, 1967).

During germination, GAs effects are antagonized by $\mathrm{ABA}$. It is known that $\mathrm{ABA}$ controls embryo maturation and prevents precocious germination by regulating gene expression. Its effect is double. First by preventing the expression of specific genes for germination, especially those which codify for hydrolases in the presence of $\mathrm{GA}_{3}$ (Fincher, 1989, Hammerton \& Ho, 1986, Jacobsen \& Beach, 1985). Second, by inducing the expression of embryogenic genes which codify for storage protein and for hydrolase-inhibiting proteins (Merlot \& Giraudat, 1997; Ingram \& Bartels, 1996; Paiva \& Kriz, 1994; Holbrook et al, 1991; Rivin \& Grudt, 1991; Williamson \& Quatrano, 1988; Bray \& Beachy, 1985; Finkelstein et al , 1985; Higgins, 1984).

Qualitative studies on the effects of these growth regulators during germination have used the electrophoresis and its derivations as the main techniques to observe the pattern of protein and mRNAs synthesis induced by these regulators (Paiva \& Kriz, 1994; Barros \& Larkins, 1990; Borges et al, 1990; Nolan \& Ho, 1988; Hammerton \& Ho, 1986; Asahi et al, 1985). In this work, the denaturating SDS-PAGE and nondenaturating PAGE - Activity Gels (polyacrylamide gels copolymerized with substrate for enzymes) systems were used in order to observe the polypeptide profile and protease activity, in embryos as well as in cotyledons of $A$. peregrina.

The choice of $A$. peregrina was due to the importance of woody species in the succession and ecological climax of most earth ecosystems and the little information at the biochemical level on the control mechanisms of germination, especially of tropical species. This species is a dicotyledon leguminous which presents quiescent seeds (orthodox) with germinative capacity higger than $85 \%$ and protein content of 
$36.5 \%$ (data non published). These characteristics added to the facility of embryo isolation, distinctly separeted from the cotyledons, make the seed of this species a good model to study, through electrophoretic analysis, the effects of $\mathrm{ABA}$ and $\mathrm{GA}_{3}$ on the mobilization of proteins in embryos and cotyledons during the germinative process.

\section{MATERIAL AND METHODS}

\section{Plant material}

Mature seeds of A. peregrina used in the experiments were obtained from the Laboratory of Forest Seeds at the Federal University of Lavras-UFLA, from a batch collected in September of 1993 and stored at $10^{\circ} \mathrm{C}$.

\section{Embryo Treatment}

-Assay for Protein Mobilization during and after the beginning of Germination

In this assay, embryos of non disinfested mature seeds were isolated after being imbibed in distilled water $\left(\mathrm{dH}_{2} \mathrm{O}\right)$ under room temperature for 5 hours. In order to analyze the effect of $\mathrm{ABA}$ and $\mathrm{GA}_{3}$ on the synthesis and/or protein degradation in embryos during the germinative process, isolated embryos were incubated in the dark at $25^{\circ} \mathrm{C}$ during $6,12,24$ and 48 hours. The incubations were performed in Petri dishes (10 embryos in each) containing two filter papers humidified with $6 \mathrm{ml}$ of $3 \%$ sucrose solution with no regulators, or supplemented with 100 $\mu \mathrm{M} \quad \mathrm{ABA} ; 1 \mu \mathrm{M} \mathrm{GA}_{3}+100 \mu \mathrm{M} \mathrm{ABA}$. In the case of the analysis of $\mathrm{ABA}$ and $\mathrm{GA}_{3}$ effects on protein synthesis and/or degradation in embryos after the germinative process had started, isolated embryos were incubated during 6 hours in the dark at $25^{\circ} \mathrm{C}$ in Petri dishes (10 embryos in each) containing two filter papers humidified in $6 \mathrm{ml}$ of $3 \%$ sucrose solution with no regulators. After this period, the embryos were transfered to $3 \%$ sucrose solutions supplemented with $100 \mu \mathrm{M} \mathrm{ABA} ; 1 \mu \mathrm{M} \mathrm{GA}_{3}$ or $1 \mu \mathrm{M} \mathrm{GA}_{3}+$ $100 \mu \mathrm{MABA}$ and incubated under the same conditions during 6, 18 and 42 hours. After the incubation periods, the embryos were stored at $-85^{\circ} \mathrm{C}$ until the electrophoretic analysis in SDS-PAGE.

\section{Cotyledon Treatment \\ -Assay for Protein Mobilization and Protease Activity in Cotyledons}

In this assay, non disinfested mature seeds were imbibed for 5 hours under room temperature in $\mathrm{dH}_{2} \mathrm{O}$ (control) or aqueous solution of $100 \mu \mathrm{M}$ $\mathrm{ABA} ; 1 \mu \mathrm{M} \mathrm{GA}_{3}$ or $1 \mu \mathrm{M} \mathrm{GA}_{3}+100 \mu \mathrm{M} \mathrm{ABA}$. After imbibition, the seeds were germinated in filter paper rolls (20 seeds in each) humidified continuously with the same treatment solutions during $0,2,4,6,8,10$ and 12 days. The germination conditions were: 8 hours of darkness at $30^{\circ} \mathrm{C}$ and 16 hours of light at $20^{\circ} \mathrm{C}$. After this, the cotyledons were isolated and stored at $-85^{\circ} \mathrm{C}$ until the electrophoretic analysis in SDS-PAGE for total protein or in PAGE-Activity Gels for proteases.

\section{Protein Extraction}

For extraction of total proteins, 5 embryos (average fresh weight $=50 \mathrm{mg}$ ) were macerated with $1 \mathrm{ml}$ of Tris- $\mathrm{HCl}$ extraction buffer [Tris-HCl $62.5 \mathrm{mM} \mathrm{pH} \mathrm{6.8;} \mathrm{2.3 \%} \mathrm{SDS;}$ $10 \%$ glicerol; 5\% $\beta$-Mercaptoetanol (Laemmli, 1970)]. Cotyledon proteins were extracted from $50 \mathrm{mg}$ of cotyledons macerated in liquid $\mathrm{N}_{2}$ and $1 \mathrm{ml}$ of the same extraction buffer. The homogenates were microcentrifuged at 16000x $g$ during 15 minutes and to the supernatant, $2 \mu \mathrm{L}$ of bromophenol blue (BFB) $(0.5 \% \mathrm{w} / \mathrm{v})$ was added. Proteases were extracted from $100 \mathrm{mg}$ of cotyledons macerated in liquid $\mathrm{N}_{2}$ and $1 \mathrm{ml}$ of sodium phosphate $50 \mathrm{mM} \mathrm{pH} 7.0$ buffer. The proteases were extracted during 2 hours at $4^{\circ} \mathrm{C}$ under occasional agitation. After extraction, the homogenate was microcentrifuged at $16000 \mathrm{x} g$ during 30 minutes at $4^{\circ} \mathrm{C}$. Glicerol and BFB up to $10 \%$ and $0.05 \%$, respectively, were added to the supernatant.

\section{Electrophoresis}

The discontinuous SDS-PAGE system described by Laemmli (1970) was used to observe the total protein profile of embryos and cotyledons. The protocol of electrophoresis in Activity Gels, obtained for proteases in A. peregrina cotyledons, was based on Asahi et al (1985) and Barros and Larkins (1990). 


\section{RESULTS AND DISCUSSION}

\section{ABA effect on the Protein Mobilization and Protease Activity during Germination}

The electrophoretic profile of total proteins extracted from cotyledons wich seeds were incubated for 12 days in the presence or absence of $\mathrm{ABA}$ and/or $\mathrm{GA}_{3}$, showed a blockage in the degradation of storage proteins in cotyledons from seeds incubated in the presence of ABA. This blockage was maintained until the $8^{\text {th }}$ day after the beginning of the treatment (Figure 1) and after this period, the protein degradation started and was rapidly completed (data not shown).

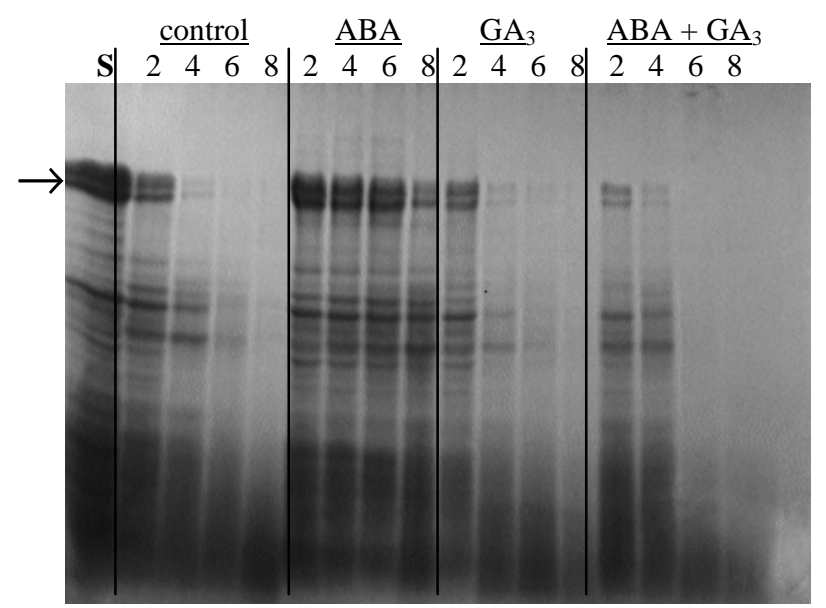

Figure 1 - Protein profile in SDS-PAGE of $A$. peregrina cotyledons isolated from seeds incubated in $\mathrm{dH}_{2} \mathrm{O}$ (control), $100 \mu \mathrm{M}$ ABA, $1 \mu \mathrm{M} \mathrm{GA}_{3}$ and 100 $\mu \mathrm{M} \mathrm{ABA}+1 \mu \mathrm{M} \mathrm{GA}_{3}$ during 2, 4, 6 and 8 days. (S), dry seed. Arrow = polypeptides with 54 to $66 \mathrm{kD}$.

The analysis of protease activity in cotyledons shows that it was inhibited until the $8^{\text {th }}$ day in the presence of ABA (Figure 2). The activity started at the $8^{\text {th }}$ day and reached maximum intensity on the $12^{\text {nd }}$ day of incubation. Initial protease activity coincided with the beginning of storage protein degradation. These data indicate that the blockage of protein degradation caused by $A B A$ was due to the inhibition of protease activity. In corn endosperm, the onset of storage protein degradation is attributed to initial protease activity (Barros \& Larkins, 1990).

From the results on germination percentage of seeds incubated in the above treatments, it was infered that protease activity and, consequently, the proteolysis of storage proteins were not fundamental for the beginning of germination. In the presence of $\mathrm{ABA}, 100 \%$ of the viable seeds germinated on the $4^{\text {th }}$ day after beginning the treatment, whereas in the control or in $\mathrm{GA}_{3}$, $100 \%$ of the viable seeds germinated on the $2^{\text {nd }}$ day. ABA delayed the germination for 2 days in relation to the control or $\mathrm{GA}_{3}$. In the presence of $\mathrm{ABA}$, the beginning of protease activity and protein degradation occurred at the $8^{\text {th }}$ day (Figures 2 and 1, respectively), 4 days after $100 \%$ of the viable seeds incubated in ABA germinated. In the control or in the presence of $\mathrm{GA}_{3}$, the beginning of protease activity and protein degradation occurred on the $2^{\text {nd }}$ day of treatment (Figures 2 and 1, respectively), coinciding with $100 \%$ germination.

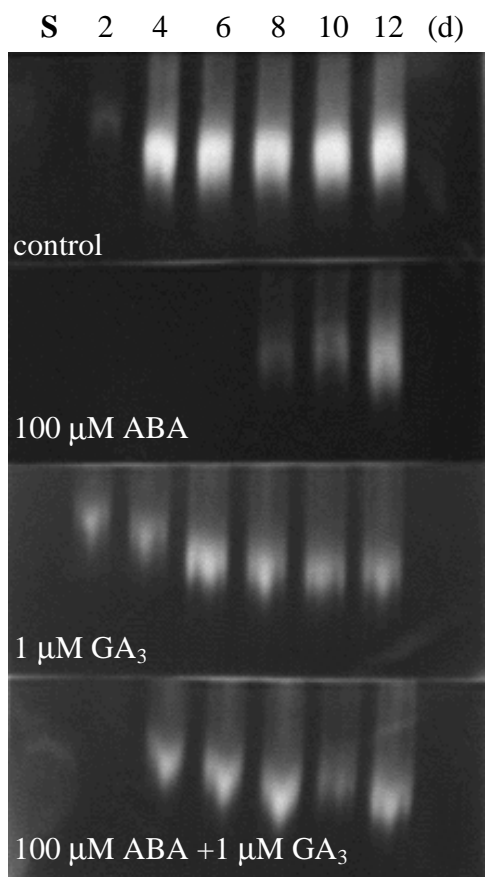

Figure 2 - Activity Gels of proteases extracted from $A$. peregrina cotyledons isolated from seeds incubated during 2, 4, 6, 8, 10 and 12 days (d) in $\mathrm{dH}_{2} \mathrm{O}$ (control) or ABA and/or $\mathrm{GA}_{3}$. (S), dry seed.

It is possible that the aminoacids translocated for protein synthesis, necessary for the initial development of the embryonic axis, were stored in dry seeds (Callis, 1995). The results with $A$. peregrina suggest that ABA has a double effect on this species, affecting germination and proteolytic activity independently. The germination could have been affected by a decrease in the cell wall extensibility and/or due to a disorganization of the actin filaments which, consequently, prevented cell division. Schopfer and Plachy (1985) analyzed the beginning of root development in Brassica napus embryos 
and they showed that increase in cell wall extensibility was the preponderant factor for water absorption by the cell. These analysis showed that ABA blocks this phase by inhibiting cell wall extensibility without affecting osmotic and turgor pressures. However, ABA affects membrane channels in guard cells by way of promoting a liquid efflux of ions, especially $\mathrm{K}^{+}$ (Leung \& Giraudat, 1998). It reduces the osmotic pressure with consequent water loss by the cell, decreasing cell turgidity and causing the closure of stomatic pore. Analyzing Schopfer and Plachy's (1985) results in relation to the effect of $\mathrm{ABA}$ in the membrane and ion channels, Hetherington and Quatrano (1991) suggest that the importance of the wall effect in response to $\mathrm{ABA}$, as much as gene expression or ion flow, varies from one tissue to another. Recent data on stomatic movement suggest that the molecular and cytoplasmic organization of actin filaments in guard cells has a movement shaping function (Leun \& Youngsook, 1997; Hwang et al, 1997). With the guard cells being turgid, the filaments are polymerized and lay radially in the cells. During induction of stomatic closure by exposure to dark or ABA, the actin filaments depolymerize and randomly occupy a cortical position adjacent to the pore. Chemical agents that depolymerize actin filaments cause the same effect of ABA or exposure to dark (Eun \& Youngsook, 1997), including efflux of $\mathrm{K}^{+}$(Hwang et al, 1997). It suggests that actin filaments are part of the signal transduction in guard cells. However, it is still unknown with what intensity or even if the actin filaments are affected by ABA during germination (which could diminish the preponderance of cell wall extensibility on germination). Therefore, considering the differentiation degree among embryonic and guard cells, it seems plausible to suppose that the opposing alterations in the turgor state between these cells in response to $\mathrm{ABA}$ are consequence of different controlling factors or different degrees of intensity of physiological response of each cell type.

The release of germination after 2 days in relation to the control and $\mathrm{GA}_{3}$ can be related to a "lag" phase, suggested by van Beckum et al (1993), in which the embryo reprograms to germinate after "release" of the endogenous ABA. However, the barley embryos with which these researchers worked, "released" to germinate after 2 days, were continuously maintained in the presence of $\mathrm{ABA}$, as in our assay. However, ABA is metabolized by the cell and a continuum of its endogenous concentration could have been established (Zeevaart \& Creelman, 1988) and suppressed by a possible gibberellin synthesis by the embryo (Fincher, 1989). Thus, it seems that the protease activity was directly affected by ABA, in whatever regulatory level, independently from the germination delay.

In embryos, the results indicated a blockage in the storage protein degradation by ABA (Figure 3 ). Protease activity in embryos was detected in 24 hours only in the control (data not shown); however, the storage protein degradation was blocked in 6 hours by ABA. It is possible that the activity not observed in the initial hours is related to the detection method and to the lower amount of protein in embryos compared to cotyledons. In a relative disagreement with our data, Borges et al (1990) found no difference on the protein profile of Piptadenia peregrina embryos, an $A$. peregrina synonym (Lewis, 1987; Allen \& Allen, 1981; Cronquist, 1981), treated with $\mathrm{ABA}$ in various concentrations up to 12 hours. An increase in the percentage of seed germination was also observed. However, these researchers isolated embryos after seeds were incubated in the presence of ABA and, according to Mayer and Shain (1974), embryo responses to regulators can be diverse between whole seeds and isolated embryos. The increase in germination percentage observed by Borges $e t$ al (1990) could be related to the low ABA concentration used $(1 \mu \mathrm{M})$. Zeevaart and Creelman (1988) reffers to stimulation of root growth by low ABA concentrations as a consequence of plant adaptation to water deficiency, made possible by ABA.

\section{Balance between $A B A$ and $G_{3}$}

According to the results of SDS-PAGE of embryo proteins, $\mathrm{GA}_{3}$ did not inhibit the ABA effect, as observed in the protein profile between embryos under $\mathrm{ABA}$ and $\mathrm{ABA}+\mathrm{GA}_{3}$ treatments (Figure 3), which showed a blockage in storage protein degradation in both treatments. However, the results show that degradation of a polypeptide with molecular weight of aproximately $17 \mathrm{kD}$ was also partially blocked by $\mathrm{GA}_{3}$ (Figure 3). This polypeptide, an albumin in our classification (data not shown), present in dry embryos, was degraded in 6 hours in the control embryos. In the presence of ABA 
and/or $\mathrm{GA}_{3}$, this degradation was blocked in 6 hours (Figure 4). If this polypeptide was a possible member of a storage protein, $\mathrm{GA}_{3}$ should not have suppressed its degradation as occurred in the presence of ABA. Nolan and Ho (1988), working with barley aleurone, found mRNAs which have their transcription suppressed by $\mathrm{GA}_{3}$ and induced by $\mathrm{ABA}$, and they suggest that the inhibition of certain genes by gibberellins is part of the action mechanism of this regulator during the induction of germination. Van Beckum et al (1993) observed that a gene responsive to $\mathrm{ABA}(R a b)$ is not suppressed by $\mathrm{GA}_{3}$, and they suggest that this gene is not part of the germinative process.

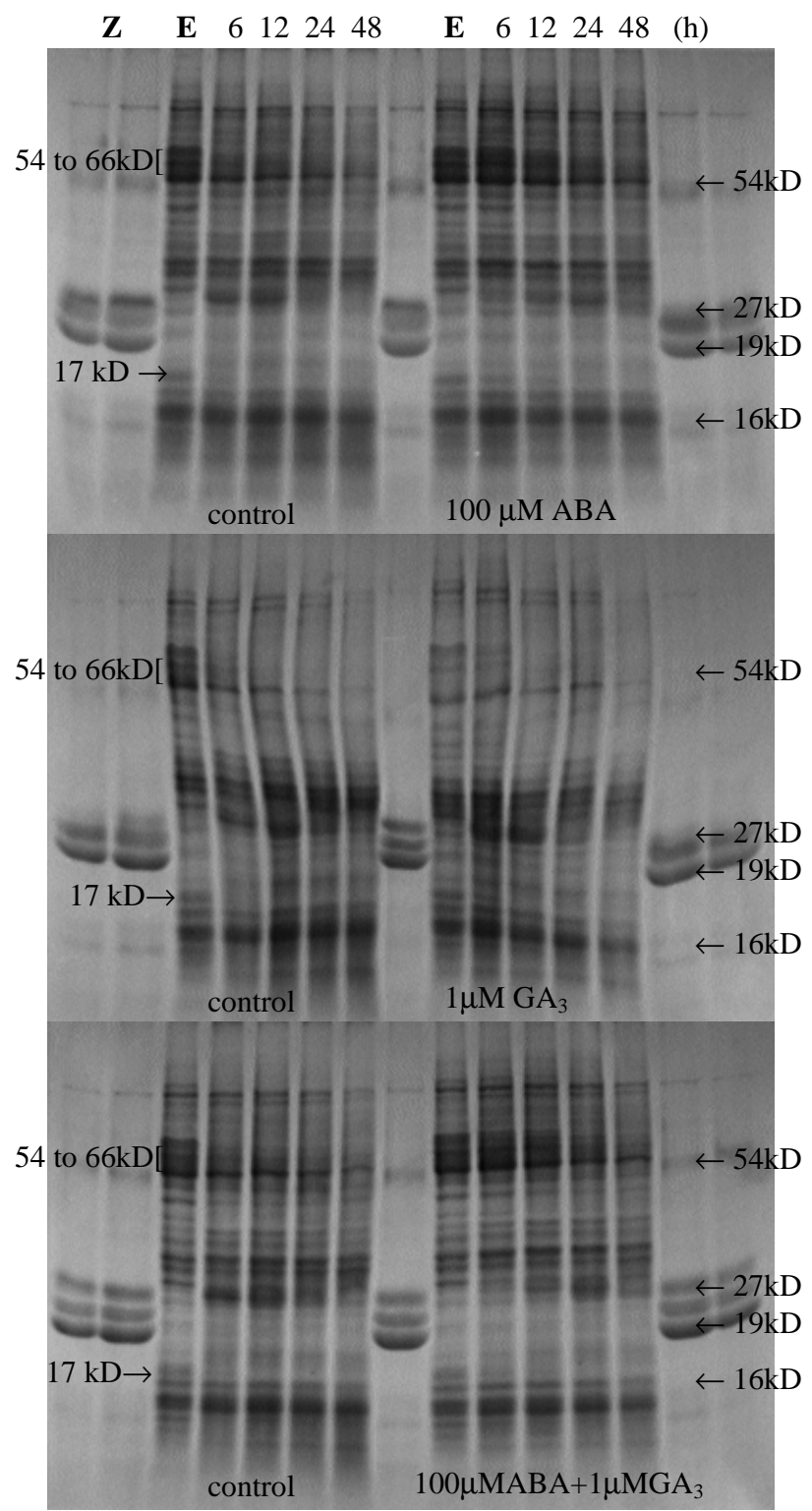

Figure 3 - Protein profile of $A$. peregrina embryos isolated from seeds imbibed in $\mathrm{dH}_{2} \mathrm{O}$ during 5 hours (E) and incubated during 6, 12,24 or 48 hours (h) in
$3 \%$ sucrose solutions supplemented with or without (control) $\mathrm{ABA}$ and/or $\mathrm{GA}_{3}$. (Z), maize prolamins (zeins) used as molecular weight marker.

However, it seems contradictory that the non degradation of the $17 \mathrm{kD}$ polypeptide induced by $\mathrm{GA}_{3}$ is related, for example, to the inhibition of a protease since $\mathrm{GA}_{3}$ apparently did not block protease activity in cotyledons (Figure 2), or to the non inhibition of a Rab gene once that the polypeptide is already present in dry embryo, degraded in the absence of ABA and probably it is not synthetized through $\mathrm{ABA}$ induction (Figure 5).

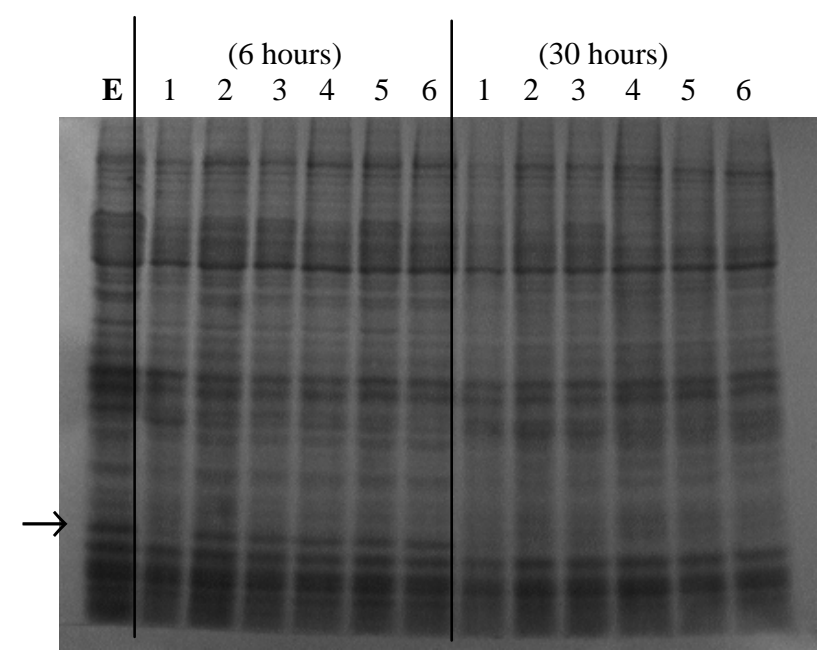

Figure 4 - Protein profile of $A$. peregrina embryos isolated from seeds imbibed in $\mathrm{dH}_{2} \mathrm{O}$ during 5 hours (E) and incubated in 3\% sucrose solutions supplemented with or without $\mathrm{ABA}$ and/or $\mathrm{GA}_{3}$ during 6 or 30 hours. 1) control, 2) $10 \mu \mathrm{M} \mathrm{ABA}, 3$ ) $100 \mu \mathrm{M}$ ABA, 4) $1 \mu \mathrm{M} \mathrm{GA}_{3}$, 5) $10 \mu \mathrm{M} \mathrm{ABA}+1 \mu \mathrm{M}$ $\mathrm{GA}_{3}$ and 6) $100 \mu \mathrm{M} \mathrm{ABA}+1 \mu \mathrm{M} \mathrm{GA}$. Arrow indicates the $17 \mathrm{kD}$-polypeptide.

In cotyledons, the effects were inverse of those observed in embryos. For the same concentration of $\mathrm{ABA}$ and $\mathrm{GA}_{3}$ used in embryos, $\mathrm{GA}_{3}$ inhibited ABA effect. Degradation of storage protein occurred in a similar way in the control as well as for embryos treated with $\mathrm{GA}_{3}$ or $\mathrm{ABA}+\mathrm{GA}_{3}$ (Figure 1). Again, the degradation seems to be related to protease activity which was inhibited by ABA, not inhibited by $\mathrm{GA}_{3}$ and partially inhibited by $\mathrm{ABA}+\mathrm{GA}_{3}$ (Figure 2). Protease activity was observed in barley aleurone treated with $1 \mu \mathrm{M}$ $\mathrm{GA}_{3}$ or $1 \mu \mathrm{M} \mathrm{GA}_{3}+100 \mu \mathrm{M} \mathrm{ABA}$ (Hammerton $\&$ Ho, 1986). There are no specific data in the literature to explain this inversion observed in $A$. peregrina. However, Torrent et al (1989) 
showed that in corn there is a degradation of endosperm protein without the embryo and they suggest the possibility of the endosperm from mature seeds contain an accumulation of gibberellins capable of inducing protease synthesis. According to Graebe (1987) inmature seeds usually have gibberellin levels not found in any other plant organ. Nowadays, genes from the biosynthetic route of GAs have been cloned, which are expressed along seeds' development (Hedden \& Kamiya, 1997; van Huizen et al, 1997). In A. peregrina, it is suggested that the addition of $\mathrm{GA}_{3}$ increased the concentration of endogenous gibberellins in a way that suppressed ABA action. According to Jacobsen $\&$ Beach (1985), an ABA excess 25 times larger than $\mathrm{GA}_{3}$ inhibits the accumulation of $\alpha$-amylase during 48 hours. After this period, this inhibition by the ABA stops.

\section{Control of Protein Synthesis by ABA}

According to the results of SDS-PAGE with embryos, all polypeptides studied were under proteolytic process and none were synthesized, in the presence or absence of $\mathrm{ABA}$ and/or $\mathrm{GA}_{3}$. The addition of $\mathrm{ABA}$ after the beginning of germination neither prevent the ongoing proteolytic process, nor induced protein synthesis (Figure 5). It could be related to the incapacity of ABA of inducing dormancy (Khan \& Andreoli, 1992). However, it is possible that more sensitive analysis, such as twodimensional electrophoresis, could reveal a polypeptide member of globulins (Paiva \& Kriz, 1994). It is also possible that the embryonic tissue of mature, non-dormant A. peregrina seeds have reduced sensitivity to ABA after the beginning of germination. Mature embryos of alfalfa (Xu \& Bewley, 1991) and B. Napus (Finkelstein et al, 1985) have complete insensitivity to $\mathrm{ABA}$, measured in relation to increasing $\mathrm{ABA}$ dosages that inhibit germination as well as in relation to the synthesis of specific proteins. In corn, ABA inhibits germination of mature embryos (Rivin \& Grudt, 1991), but mRNAs for globulins were detected in embryos incubated in ABA after the beginning of germination (Paiva \& Kriz, 1994). The fact that A. peregrina has non-dormant seeds, could also be related to its insensitivity to ABA. Van Beckum et al (1993) studied the germination of isogenic embryos from dormant and nondormant barley seeds, both acquired through maturation of seeds from the same line, under conditions of short and long day, respectively. Their studies show that the inhibition of germination by ABA depends on the concentration of exogenous $\mathrm{ABA}$ and that embryos from dormant seeds are more sensitive to $\mathrm{ABA}$, as far as germination inhibition, than embryos from non-dormant seeds.

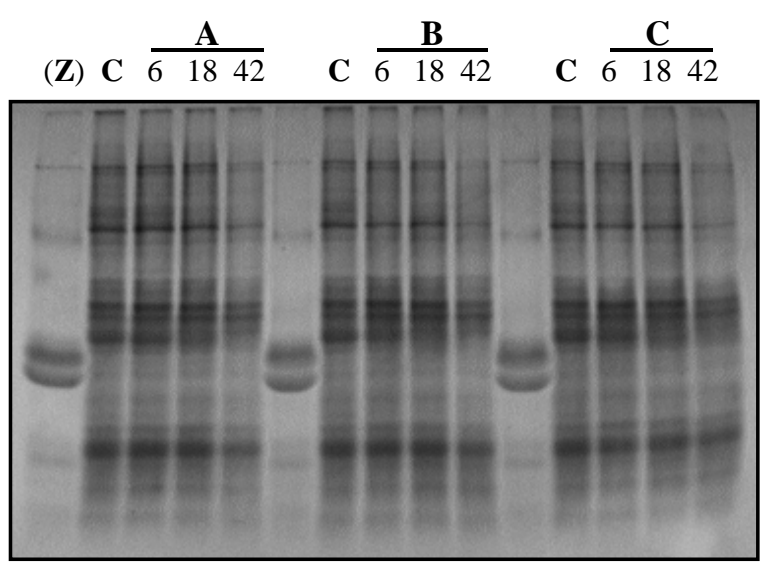

Figure 5 - Protein profile of A. peregrina embryos isolated from seeds imbibed in $\mathrm{dH}_{2} \mathrm{O}$ during 5 hours and incubated in 3\% sucrose solutions during 6 hours (C), then transferred and incubated during 6,18 and 42 hours in $3 \%$ sucrose solutions supplemented with A- $100 \mu \mathrm{M}$ ABA, B- $1 \mu \mathrm{M} \mathrm{GA}_{3}$ and C- $1 \mu \mathrm{M} \mathrm{GA}+$ $100 \mu \mathrm{M}$ ABA. $(\mathbf{Z})$, maize prolamin (zeins) used as a molecular weight marker.

However, in A. peregrina cotyledons under $\mathrm{ABA}$ treatment, the presence of a polypeptide group with molecular weight higher than $66 \mathrm{kD}$ was observed until the $6^{\text {th }}$ day of incubation (Figure 1), after which they disappeared coinciding with the beginning of protease activity. The results show that some of these polypeptides were present with low intensity in dry seed, and in the presence of $\mathrm{ABA}$, an increase in intensity of these polypeptides occurred, as well as the appearance of new polypeptides. This result is in agreement with the literature as to the ABA's capacity of inducing protein synthesis, already mentioned in this study. However, the nature of these polypeptides was not determined, whether they 
are part of storage globulins, as in other dicotyledons, or part of protease inhibitors.

\section{CONCLUSIONS}

The results obtained with $A$. peregrina reveal the importance of studing wild species, at least where the antagonism between $\mathrm{ABA}$ and $\mathrm{GA}_{3}$ in controlling germination is concerned. The degradation of the $17 \mathrm{kD}$-polypeptide shows that the effects of these regulators could diverge from what is reported for cultivated species. However, this is an isolated result and more specific analysis should be performed in order to confirm if this is a direct relation. As to the protein mobilization as a whole, the data obtained do not markedly diverge from the available data in literature, although it was not clearly shown in embryos that the blockage of proteolytic activity is related to the blockage of enzyme activity, as shown in cotyledons.

\section{RESUMO}

Controle da Mobilização de Proteínas pelo ABA e $\mathrm{GA}_{3}$ em Sementes de Angico [Anadenanthera peregrina ( L. ) Speg.] durante a Germinação.

Estudou-se a germinação de uma espécie selvagem sob influência do ABA e $\mathrm{GA}_{3}$. Embriões isolados, incubados em soluções de sacarose contendo ABA e/ou $\mathrm{GA}_{3}$, foram analizados em SDS-PAGE para observar o perfil da mobilização de proteínas de reserva durante o início da germinação. Cotilédones de sementes incubadas em soluções aquosas de ABA e/ou $\mathrm{GA}_{3}$ foram analizados em SDS-PAGE e PAGE/Géis de Atividade para observar o perfil da mobilização de proteínas de reserva e atividade de proteases, respectivamente, após o início da germinação. Os resultados indicam que ABA bloqueia a mobilização protéica através da inibição da atividade enzimática em cotilédones, mas não impede totalmente a germinação, parecendo afetar germinação e atividade enzimática independentemente. Em embriões houve bloqueio da mobilização, mas a relação com a inibição da atividade enzimática não foi claramente demonstrada. ABA induziu a síntese de proteínas em cotilédones, mas não em embriões. Um polipeptídeo com $17 \mathrm{kD}$ é degradado em 6 horas nos embriões, mas a degradação é bloqueada por $\mathrm{ABA}$ e/ou $\mathrm{GA}_{3}$. Para mesmas concentrações de $\mathrm{ABA}$ e $\mathrm{GA}_{3}$, $\mathrm{GA}_{3}$ não inibiu o efeito do $\mathrm{ABA}$ em embriões, mas inibiu em cotilédones. Os efeitos do $\mathrm{ABA}$ e $\mathrm{GA}_{3}$ não diferiram sensivelmente dos dados correntes, mas o comportamento do polipeptídeo de $17 \mathrm{kD}$ é contraditório e sugere estudos específicos.

\section{REFERENCES}

Allen, O.N; Allen, E.K. (1981), The Leguminosae - A source book of characteristics, uses and nodulation. Wisconsin Press, USA

Asahi, M.; Lindquist, R.; Fukuyama, K.; Apodaca, G.; Epstein, W. L.; McKerrow, H. (1985), Purification and characterization of major extracellular proteinases from Tricophytum rubrum. Biochem. J., 232, 139144

Barros, E.G.; Larkins, B.A. (1990), Purification and characterization of zein-degrading proteases from endosperm of germinating maize seeds. Plant Physiol., 94, 297-303

Borges, E. E. L.; Novais, A. B.; Borges, R. C. G. (1990), Controle da germinação de sementes de Angico vermelho (Piptadenia peregrina) pelo ácido abscísico. R. Bras. Sement., 12(2), 9-16

Bray, E. A.; Beachy, R. N. (1985), Regulation by $\mathrm{ABA}$ of $\beta$-conglycinin expression in cultured developing soybean cotyledons. Plant Physiol., 79, 746-750

Callis, J. (1995), Regulation of protein degradation. Plant Cell, 7, 845-857

Cronquist, A. (1981), An Integrated System of Classification of Flowering Plants. Columbia Univ. Press, New York

Eun, S-O.; Yeoungsook, L. (1997), Actin filaments of guard cells are reorganized in response to light and abscisic acid. Plant Physiol., 115, 1491-1498

Fincher, G. B. (1989), Molecular and cellular biology associated with endosperm mobilization in germinating cereal grains. Annu. Rev. Plant Physiol. Plant. Mol. Biol., 40, 305-346 
Finkelstein, R.; Tenbarge, K. M.; Shumway, J.E.; Crouch, M. L. (1985), Role of ABA in maturation of rapessed embryos. Plant Physiol., 78, 630-636

Graebe, J. E. (1987), Gibberellin biosynthesis and control. Annu. Rev. Plant Physiol., 38, 419-465

Hammerton, R. W.; Ho, T-H. D. (1986), Hormonal regulation of the development of protease and carboxipeptidase activities in barley aleurone layers. Plant Physiol., 80, 692-697

Harvey, B. M. R.; Oaks, A. (1974), The role of gibberellic acid in the hydrolysis of endosperm reserves in Zea mays. Planta, 121, 67-74

Hedden, P.; Kamiya, Y. (1997), Gibberellin biosynthesis - enzymes, genes and their regulation. Annu. Rev. Plant Physiol. Plant Mol. Biol., 48, 431-460

Hetherington, A. M.; Quatrano, R. S. (1991), Mechanisms of action of abscisic acid at the cellular level. New Phytol., 119, 9-32

Higgins, T.J. (1984), Synthesis and regulation of major proteins in seeds. Annu. Rev. Plant Physiol., 35, 191-221

Higgins, T.J.; Zwar, J.A.; Jacobsen, J. V. (1976), Gibberellic acid enhances the level of translatable mRNA for $\alpha$-amylase in barley aleurone layers. Nature, 260, 166-168

Holbrook, L. A.; van Rooijen, G.J.H.; Willen, R.W.; Moloney, M. M. (1991), Oilbody proteins in microspore-derived embryos of Brassica napus. Plant Physiol., 97, 10511058

Hwang, J-U; Sujeoung, S.; Hanju, Y.; Jimok, K.; Yeoungsook, L. (1997), Actin filaments modulate both stomatal opening and inward $\mathrm{K}^{+}$-channel activities in guard cells of Vicia faba L. Plant Physiol., 115, 335-342

Ingram, J; Bartels, D. (1996), The molecular basis of dehydration tolerance in plants. Annu. Rev. Plant Physiol. Plant Mol. Biol., 47, 377-403

Jacobsen, J. V.; Beach, L. R. (1985), Control of transcription of $\alpha$-amylase and rRNA genes in barley aleurone protoplasts by gibberellin and abscisic acid. Nature, 316, 276-277

Jacobsen, J.V.; Varner, J. E. (1967), Gibberellic acid - induced synthesis of protease by isolated aleurone layers of barley. Plant Physiol., 42, 1596-1600
Khan, A. A.; Andreoli, C. (1992), Hormonal control of seed dormancy and germination under stressful and nonstressful conditions. $4^{\text {th }}$ International Workshop on Seeds, France

Kohler, S. M.; Ho, T-H. D. (1990), Hormonal regulation, processing, and secretion of cysteine proteinases in barley aleurone layers. Plant Cell, 2, 769-783

Laemmli, U. K. (1970), Cleavage of structural protein during the assembly of head of bacteriophage T4. Nature, 227, 680-685

Larkins, B. A. (1981), Seed storage proteins characterization and biosynthesis. In- The Biochemistry of Plants, 6, 449-489

Leung, J.; Giraudat, J. (1998), Abscisic acid signal transduction. Annu. Rev. Plant Physiol. Plant Mol. Biol., 49, 199-222

Lewis, G.P. (1987), Legumes of Bahia. Royal Botanic Gardens, UK, pp. 116-123

McCarty, D.R. (1995), Genetic control and integration of maturation and germination pathways in seed development. Annu. Rev. Plant Physiol. Plant Mol. Biol., 46, 71-93

Mayer, A. M.; Poljakoff-Mayber, A. (1989), The Germination of Seeds. Pergamon Press, U.K.

Mayer, A. M.; Shain, Y. (1974), Control of seed germination. Annu. Rev. Plant Physiol., 25, 167-193

Merlot, S.; Giraudat, J. (1997), Genetic analysis of abscisic acid signal transduction. Plant Physiol., 114, 751-757

Nolan, R. C.; Ho, T-H. D. (1988), Hormonal regulation of gene expression in barley aleurone layers. Planta, 192, 332-339

Oishi, M. Y.; Bewley, J. D. (1992), Premature drying, fluridone-treatment, and embryo isolation during development of maize kernels (Zea mays L.) induce germination but the protein synthetic responses are different. Potential regulation of germination and protein synthesis by abscisic acid. J. Exp. Bot., 43, 759-767

Paiva, R.; Kriz, A. L. (1994), Effect of abscisic acid on embryo-specific gene expression during normal and precocious germination in normal and viviparous maize (Zea mays) embryos. Planta, 192, 332-339

Qi, X.; Wilson, K. A.; Tan-Wilson, A. L. (1992), Characterization of the major protease involved in the soybean $\beta$ conglycinin storage protein mobilization. Plant Physiol., 99, 725-733 
Rivin, C. J.; Grudt, T. (1991), Abscisic acid and the developmental regulation of embryo storage proteins in maize. Plant Physiol., 95, 358-365

Ryan, C. A. (1973), Proteolytic enzymes and their inhibitors in plants. Annu. Rev. Plant Physiol., 24, 173-196

Schopfer, P; Plachy, C. (1985), Control of seed germination by abscisic Acid. III- Effect on embryo growth potential (minimum turgor pressure) and growth coefficient (cell wall extensibility) in Brassica napus L. Plant Physiol, 77, 676-686

Shewry, P. R.; Napier, J. A.; Tatham, A. S. (1995), Seed storage proteins: structures and biosynthesis. Plant Cell, 7, 945-956

Shotwell, M. A.; Larkins, B. A. (1989), The biochemistry and molecular biology of seed storage proteins. In- The Biochemistry of Plants, 15, 297-345

Shutov, A. D.; Vaintraub, I.A. (1987), Degradation of storage proteins in germinating seeds. Phytochem., 26, 15571566

Torrent, M.; Gelli, M. I.; Ludevid, M. D. (1989), Storage-proteins hydrolysis and protein-body breakdown in germinated Zea mays L. seeds. Planta, 180, 90-95
Van Beckum, J. M. M.; Libbenga, K. R.; Wang, M. (1993), Abscisic acid and gibberellic acid-regulated responses of embryos and aleurone layers isolated from dormant and nondormant barley grains. Physiol. Plant., 89, 483-489

Van Huizen, R; Ozga, J.A.; Reineck, D.M. (1997), Seed and hormonal regulation of gibberellin 20-oxidase expression in pea pericarp. Plant Physiol, 115, 123-128

Xu, N.; Bewley, J. D. (1991), Sensitivity to abscisic acid and osmoticum changes during embryogenesis of alfafa (Medicago Sativa). J. Exp. Bot., 42, 821-826

Williamson, J. D.; Quatrano, R. (1988), ABAregulation of embryo-specific sequences in mature wheat embryos. Plant Physiol., 86, 208-215

Zeevaart, J. A. D; Creelman, R. A. (1988), Metabolism and physiology of abscisic acid. Annu. Rev. Plant Physiol. Plant Mol. Biol., 39, 439-473

Received: August 08, 1997; Revised: September 15, 1997 Accepted: April 28, 1999. 